\title{
Epstein-Barr virus infection in transplant recipients: Summary of a workshop on surveillance, prevention and treatment
}

\author{
Upton Allen MBBS MSc FAAP FRCPC 1 , Caroline Alfieri PhD², Jutta Preiksaitis MD FRCPC ${ }^{3}$, \\ Atul Humar MD FRCPC ${ }^{4}$, Dorothy Moore MD FRCPC ${ }^{5}$, Bruce Tapiero MD FRCPC ${ }^{2}$, \\ Raymond Tellier MD MSc FRCPC ${ }^{6}$, Michael Green MD MPH ${ }^{7}$, \\ Dele Davies MD MSc FRCPC ${ }^{8}$, Diane Hébert MD FRCPC ${ }^{9}$, Sheila Weitzman MD FRCPC ${ }^{10}$, \\ Martin Petric PhD FCCM ${ }^{6}$, Kevan Jacobson MD FRCPC ${ }^{11}$, \\ and the Canadian PTLD Workshop Group - 1999
}

U Allen, C Alfieri, J Preiksaitis, et al. Epstein-Barr virus infection in transplant recipients: Summary of a workshop on surveillance, prevention and treatment. Can J Infect Dis 2002;13(2):89-99.

Diseases caused by the Epstein-Barr virus are of great significance among organ transplant recipients. One of these diseases, posttransplant lymphoproliferative disease, is a major complication among organ transplant recipients. Management of this entity is problematic due to the difficulties with laboratory surveillance, diagnosis, prevention and treatment. A group of Canadian and American experts was assembled to discuss these aspects of Epstein-Barr virus diseases in Canadian organ transplant recipients. This report summarizes the relevant background literature and levels of evidence in relation to the outcomes of the deliberations and recommendations by the expert panel.

Key Words: Epstein-Barr virus; Lymphoproliferative disease; Transplantation
Infections à virus Epstein-Barr chez des greffés : résumé d'un atelier sur la surveillance, la prévention et le traitement de ces maladies

RÉSUMÉ : Les maladies causées par le virus Epstein-Barr revêtent une grande importance pour les greffés. En effet, l'une d'entre elles, le syndrome lympho-prolifératif post-transplantation, est une complication grave rencontrée chez les receveurs d'organes. La prise en charge des patients atteints pose problème en raison des difficultés liées à la surveillance de la maladie en laboratoire, à son diagnostic, à sa prévention et à son traitement. Un groupe d'experts canadiens et américains a été formé pour discuter des infections à virus Epstein-Barr observées dans la population de greffés au Canada. Le présent rapport offre un résumé de la documentation scientifique sur la question et des niveaux de preuve sur lesquels s'appuient les discussions et les recommandations formulées par le groupe.

The workshop on Epstein-Barr virus infection in transplant recipients took place from December 3 to 4, 1999 in Toronto, Ontario

${ }^{1}$ Division of Infectious Diseases, The Hospital for Sick Children, Toronto, Ontario; ${ }^{2}$ Hôpital Ste-Justine, Montreal, Québec; ${ }^{3}$ Division of Infectious Diseases, University of Alberta, Edmonton; ${ }^{4}$ Division of Infectious Diseases, The Toronto Hospital, Ontario; ${ }^{5}$ Montreal Children's Hospital, Québec; ${ }^{6}$ Department of Paediatric Laboratory Medicine, The Hospital for Sick Children, Toronto, Ontario; ${ }^{7}$ University of Pittsburgh, Pennsylvania; ${ }^{8}$ Division of Infectious Diseases, University of Calgary, Alberta; ${ }^{9}$ Division of Nephrology, The Hospital for Sick Children, Toronto, Ontario; ${ }^{10}$ Division of Haematology/Oncology, The Hospital for Sick Children, Toronto, Ontario; ${ }^{11}$ British Columbia's Children's Hospital, Vancouver, and the Canadian PTLD Workshop Group-1999

Correspondence and reprints: Dr Upton D Allen, Division of Infectious Diseases, The Hospital for Sick Children, 555 University Avenue,

Toronto, Ontario M5G 1X8. Telephone 416-813-8129, fax 416-813-8404, e-mail upton.allen@sickkids.ca

Received for publication July 19, 2001. Accepted October 15, 2001 
$T_{\text {it }}^{\text {he }}$ he Epstein-Barr virus (EBV) is recognized primarily for its etiological role in infectious mononucleosis, a usually benign lymphoproliferative disorder most prevalent in adolescents and young adults. Under conditions of severe T cell immunosuppression, which prevail in patients with AIDS and transplant recipients, EBV-infected B cells may expand unchecked, resulting in malignant lymphoproliferation. In this context, the virus is able to transform and immortalize B lymphocytes, leading to their uncontrolled proliferation (1). This is particularly likely in settings where the host lacks adequate cytotoxic $\mathrm{T}$ lymphocyte surveillance. One such setting occurs when transplant recipients experience primary EBV infection.

The majority of these tumours, known collectively as B cell lymphoproliferative disorders or 'post-transplant lymphoproliferative disease' (PTLD), when present in transplant recipients, are EBV-associated and often occur within the first year following transplantation (2-6). Histologically, they are categorized as polymorphic diffuse B cell hyperplasia or polymorphic B cell lymphomas $(2,3)$. Classical PTLD originates as a polyclonal expansion of EBV-infected B cells but may evolve into oligoclonal or monoclonal lesions (7). Primary EBV infection is a major risk factor for development of these tumours; however, PTLD has also been documented in patients with reactivated infection (8). Thus, the incidence of PTLD is greater in children than in adults, with rates of $4 \%$ to $22 \%$ reported for the various categories of paediatric organ transplant recipients versus an average of $1 \%$ to $2 \%$ in adults $(2,3,9-12)$. This difference between adults and children is understandable in view of the fact that in EBV-seronegative transplant recipients, EBV infection rates are high (9-12), approaching $100 \%$ within three months after transplantation (9). Children are more likely to contract primary EBV infection after transplantation, usually from the donor organ or blood transfusions $(13,14)$, because many are EBV-seronegative before transplantation. In developed countries, EBVseropositivity rates increase with age; therefore, in the general population of children one to 18 years of age, up to 50\% are EBV-seropositive, compared with a 90\% seropositivity rate in adults $(15,16)$. These figures also apply to the transplant population $(8,10,17)$.

While in some settings patient and graft survivals are excellent following the diagnosis of PTLD (18), in other settings this entity is generally associated with a poor prognosis (12). This is related in part to difficulties with early diagnosis, prevention and treatment. In addition, poor outcomes may be related to rejection that may follow the reduction in immunosuppression used to treat PTLD. In this regard, this paper discusses the delicate balance between reduced immunosuppression aimed at controlling PTLD and the potential adverse consequence of such reduced immunosuppression, namely rejection. Moreover, data are lacking on the effectiveness of prophylactic and treatment strategies. A multidisciplinary group was assembled to discuss these issues and to arrive at a consensus wherever possible.
TABLE 1

Categories indicating the strength of the evidence for or against each recommendation

\begin{tabular}{ll}
\hline Category & Definition \\
\hline A & $\begin{array}{l}\text { Good evidence to support a recommendation } \\
\text { for use } \\
\text { B }\end{array}$ \\
Moderate evidence to support a recommendation \\
for use \\
Poor evidence to support a recommendation \\
against use \\
Good evidence to support a recommendation \\
\end{tabular}

TABLE 2

Categories indicating the quality of the evidence on which recommendations are based

\begin{tabular}{ll}
\hline Level & Definition \\
\hline I & Evidence from at least one properly randomized con- \\
trolled trial & Evidence from at least one well-designed clinical trial \\
& without randomization, from cohort or case-controlled \\
& analytical studies, (preferably from more than one \\
& centre), from multiple time series, or dramatic results in \\
& uncontrolled experiments \\
& Evidence from opinions of respected authorities on the \\
III & basis of clinical experience, descriptive studies, or \\
& reports or expert committees
\end{tabular}

\section{METHODS}

The multidisciplinary group consisted of infectious diseases and transplant physicians, transplant surgeons, oncologists and virologists from the major transplant centres in Canada. The group included individuals who were selected because they were recognized as leaders in the study of PTLD and/or EBV infections.

Following plenary presentations by the experts, workshops were conducted with the following objectives: to summarize succinctly the most relevant data; to arrive at a consensus agreement on key issues relating to laboratory surveillance, prevention and treatment of PTLD; and where no clear consensus was possible, to summarize the different options relating to the above issues. Each panel consisted of approximately 10 individuals with an audience of approximately 40 who participated in the discussions. The background information and the outcome of each workshop are summarized in this report. Wherever recommendations were made, the levels of supporting evidence were categorized as indicated in Tables 1 and 2. Where there was no consensus or evidence to support firm conclusions, the approaches used at major Canadian or American institutions were summarized. 


\section{RESULTS}

\section{Summary of supporting evidence}

Laboratory surveillance for EBV-related PTLD: Given the very poor prognosis of PTLD, early diagnosis is essential to maximize the chances of a successful outcome. Ideally, this would require an appropriate surveillance system. In addition to the issue of early detection, treatment or prevention of PTLD relies on an accurate diagnosis and the ability to distinguish it from graft rejection, particularly when the major pathology involves the transplanted organ. In addition, the clinical management of PTLD entails the reduction of immunosuppressive medication with the potential complication of rejection. Because of the difficulties that may be encountered in distinguishing EBV-positive lymphoid infiltrates from rejection (19), markers have been sought to confirm the presence of EBV and to evaluate the relative risk for PTLD development in different clinical scenarios.

Serological markers: Because primary EBV infection is a risk factor for the development of PTLD, it is essential to identify patients at risk by performing EBV serology before transplantation. As previously mentioned, the patients at highest risk of PTLD are EBV-seronegative recipients who received EBV-seropositive organs. After transplantation, such patients should be monitored for the acquisition of EBV infection.

Experience has shown that serology is unreliable as a diagnostic tool for either PTLD or primary EBV infection in immunocompromised patients. These patients show a marked delay in their humoral response to EBV antigens, and many fail to develop immunoglobulin (Ig) M antibodies altogether (20). Another important drawback is that these patients often receive blood or blood products with the passive transfer of donor antibodies.

At the Canadian National Centre for EBV, antibody titres to the Epstein-Barr nuclear antigen complex (EBNA) are determined by anticomplement immunofluorescence on Raji cells fixed in a chilled 1:1 mixture of acetone to methanol for 3 min (21). MOLT-4 cells serve as negative controls for antinuclear staining. Antibody titres to EBNA-2 are determined by anticomplement immunofluorescence on $\mathrm{BJAB}$ cells transfected with the EBNA-2 gene fragment and fixed as above (22). Antibody titres to viral capsid antigen IgG are determined by standard indirect immunofluorescence on productively infected cell lines such as B95-8 or P3HR-I fixed in chilled acetone for $10 \mathrm{~min}$ (23). Antibody titres to early antigen are determined by standard indirect immunofluorescence on 5-bromo 2'-deoxyuridine (BrdU)-treated Raji cells fixed in acetone (24). Commercially available slides obtained from GRANBIO (Temecula, USA) are a suitable alternative.

Detection of EBV nucleic acids or protein in tissue: In situ analysis of biopsy specimens by viral antigen (6) or EBVencoded small nuclear RNA (EBER) (25) detection has been reported to be a valuable method to assist in the diagnosis of PTLD. These methods, however, have limited prognostic value and may lack sensitivity in cases of diffuse PTLD.
Viral load determination in the peripheral blood: An early study published by Rocchi et al (26) was the first to suggest a relationship between PTLD and the number of EBV-infected cells in peripheral blood. This study reported that healthy EBV-seropositive individuals had a peripheral blood count of 0.1 to 1 EBV-immortalizing unit $/ 10^{6}$ peripheral blood mononuclear cells (PBMCs) as determined by limiting dilution co-culture with cord blood leukocytes. Parallel experiments with patients with acute phase, infectious mononucleosis indicated that their EBV load in peripheral blood was many-fold higher, at about 500 to 2000/106 PBMC. In 1994, Riddler et al (27) and Savoie et al (9) independently reported that an abnormally elevated EBV viremia correlated with PTLD development. Using a limiting dilution culture technique similar to that described by Rocchi et al (26), work in the laboratory of Alfieri showed that patients with PTLD had 1000 or more EBV-immortalizing units $/ 10^{6}$ PBMC (9). Data from the Riddler study indicated that using semiquantitative polymerase chain reaction (PCR), patients with PTLD had a viral load greater than 5000 EBV genome copies $/ 10^{6}$ PBMC (27). Other studies confirmed these findings (28-33). An association between PTLD and EBV detection in plasma has also been reported (33). However, the bulk of the work done to date has focused on viral load determined in PBMCs.

All of the above studies have advocated the establishment of a threshold value for EBV viremia to distinguish high risk PTLD patients from those at low risk. Data from two Canadian centres indicate that the negative predictive values of different levels of EBV viremia are in the region of $90 \%$ to $100 \%$, while the positive predictive values are only $50 \%$ to $60 \%$ at best $(34,35)$. The characteristics of this test as a diagnostic indicator of the presence of PTLD indicate that it is more useful in ruling out PTLD than in indicating its presence, in keeping with the poor positive predictive value and high negative predictive values cited above (35). Thus, a second marker for prediction of PTLD in patients with high viral load is being sought. This is the subject of investigations by different groups. In addition, it would be desirable to have a uniform way of reporting EBV viral load. This would assist laboratories and clinicians to apply better the results of studies performed in settings other than their own.

An extensive review of the various methods used in Canada is outside the scope of this summary. The approaches used at two of Canada's leading transplant centres are summarized in Appendix 1.

EBV prophylaxis among solid organ transplant recipients: Experience to date with transplant recipients indicates that cytomegalovirus (CMV) accounts for the major proportion of significant herpes group-related diseases. In this regard, various strategies have been developed and evaluated for the prevention of CMV infection and disease (36). These approaches include blood-banking techniques, the use of antiviral agents, immunoprophylaxis with active vaccina- 
tion and passive antibody therapy. However, in the case of EBV, the role of these approaches in preventing EBV infection among transplant recipients is less well established. Prevention of EBV infection in seronegative patients would be ideal given that this virus is responsible for one of the most devastating complications among transplant recipients, namely PTLD $(37,38)$. As mentioned previously, in causing PTLD, the oncogenic potential of the virus is manifested by its ability to transform and immortalize B lymphocytes, leading to the potential for uncontrolled proliferation of B cells (1). Transplant recipients who are EBV seronegative and who receive a seropositive organ are the prime targets for EBV preventive strategies because they are at the greatest risk of PTLD $(8,39)$. A number of studies have addressed the potential role and the current evidence for antiviral agents and immunoglobulin in preventing EBV infection, as well as EBV-related PTLD.

Severe combined immunodeficiency disease mouse model: There is evidence for a possible beneficial effect of antiviral agents and immunoglobulin in preventing tumours in the severe combined immunodeficiency disease (SCID) mouse model of PTLD.

Antiviral agents: In a study by Boyle et al (40), five groups of SCID mice were evaluated: group 1 consisted of controls that were engrafted with peripheral blood lymphocytes (PBL) from EBV-seronegative donors; mice in group 2 were engrafted with PBL from EBV-seropositive donors (latently infected); group 3 was similar to group 1, except that they were also actively infected with EBV; group 4 was similar to group 2, except that they were also actively infected with EBV; group 5 was engrafted with EBV-transformed B lymphoblastoid cell lines (BLCL). Mice within the groups were treated with intraperitoneal cyclosporine, intraperitoneal methylprednisolone, oral acyclovir or intraperitoneal ganciclovir.

Tumours did not develop in mice that were engrafted with PBLs from seronegative donors. However, in animals that were also inoculated with EBV, tumours developed at a median of 31 days after engraftment. Mice that were engrafted with PBLs from seropositive donors developed tumours at a median of 76 days. If these animals were also actively inoculated with EBV, tumours developed at a median of 37 days. After engraftment with $5 \times 10^{6} \mathrm{BLCL}$, tumours developed in all the mice at a median of 19 days after engraftment.

The use of cyclosporine and methylprednisolone did not affect the rate of development of tumours after active infection or after engraftment of BLCL. Surprisingly, cyclosporine treatment of mice engrafted with PBLs from seropositive donors inhibited the development of tumours. No tumours were observed in these mice when they were treated with methylprednisolone or cyclosporine singly, or in combination. In these animals, the investigators confirmed that engraftment had occurred by the detection of human IgG in serum and human lymphocytes in peritoneal washings.

Orally administered acyclovir treatment had no effect on the development of tumours. In contrast, ganciclovir treatment led to prolonged survival and a lower incidence of tumours in actively infected mice, as well as those engrafted with BLCL.

Immunoglobulin: Abedi et al (41) studied the effects of weekly treatments with different immunoglobulin preparations on the development of human B cell tumours in SCID mice. The mice were injected intraperitoneally with human PBMCs from an EBV-seropositive healthy blood donor. The repopulated mice were divided into eight treatment groups, including a control group. The results indicated that immunoglobulin-treated mice did not develop tumours when weekly treatment was started on day +1 after repopulation at a dose of $50 \mathrm{mg} / \mathrm{week}$. The animals in the control group were treated with phosphate-buffered saline and $83 \%$ developed tumours within 150 days. Mice that received lower doses of immunoglobulin and fewer treatments were more likely to develop tumours than those receiving higher doses. In addition, those that had the delayed onset of immunoglobulin treatment were more likely to have tumours. In additional experiments, mice that received immunoglobulin from EBV-seronegative donors were more likely to develop tumours compared with those that received immunoglobulin from EBV-seropositive donors. These findings suggest that administration of immunoglobulin with EBV antibodies is beneficial in preventing EBVinduced lymphoproliferative disease.

Studies in transplant recipients: Given that ganciclovir is more active than acyclovir against EBV, emphasis was placed on studies in which the former agent was used. Reports relating to solid, as well as bone marrow transplant recipients, have made reference to the role of acyclovir as the sole antiviral agent in EBV or PTLD prophylaxis; however, for the most part, the studies were not designed to address this question (42-46).

There are five published studies concerning solid organ transplant recipients that have addressed the issue of EBV prophylaxis with ganciclovir or acyclovir (47-51). None of these studies addressed the role of immunoglobulin. Of these studies, two were prospective $(47,48)$, of which one was a randomized trial (47). However, the studies were not designed to look at the efficacy of ganciclovir and/or acyclovir for the prevention of PTLD. Only the three retrospective studies looked at the question of the efficacy of antiviral agents for the prevention of PTLD.

In a study by Keay et al (49), the development of PTLD during the first 62 days after pancreas transplantation was associated with a lack of ganciclovir or acyclovir prophylaxis. This study was limited by its retrospective design and a low event rate. Results from a study by Darenkov et al (51) suggested that prophylactic antiviral therapy might reduce the incidence of PTLD when administered during antilymphocyte antibody treatment. The study was limited by a lack of concurrent controls because the authors used historical controls. The study by Davis et al (50) was also limited by the use of historical controls. Although the authors reported that the incidence of PTLD in patients receiving intravenous ganciclovir followed by oral acyclovir 
was lower than previously observed at their centre, the unavailability of a concurrent control group limits the conclusions that can be drawn.

Green et al (47) compared intravenous ganciclovir followed by oral acyclovir with intravenous ganciclovir alone for prevention of CMV and EBV disease after liver transplantation. The study used a randomized design; 48 children were enrolled. EBV disease was defined as the identification of EBV in blood cells by histological staining using EBER probes. Symptomatic disease was categorized as adenopathic disease, mononucleosis, extranodal disease or lymphoma. The rate of EBV disease among patients treated with the combination regimen was similar to that among patients treated with ganciclovir alone. The authors observed a trend toward an increased frequency of EBV disease in patients treated with long term, high dose acyclovir compared with those treated with ganciclovir alone.

McDiarmid et al (48) enrolled consecutive first-time orthotopic liver transplant recipients in their study. These patients were stratified into two groups; group 1 (high risk, donor EBV-seropositive, recipient seronegative [D+R-]) received intravenous ganciclovir for 100 days followed by oral acyclovir until the end of the second year after transplantation. Group 2 (donor EBV-seropositive, recipient seropositive and donor EBV-seronegative, recipient seronegative [D-R-]) received intravenous ganciclovir for 14 days followed by oral acyclovir until the end of the second year. Study patients were monitored with semiquantitative EBV PCR at intervals of every one to three months for two years. Patients had immunosuppressive medications modified and ganciclovir was started if they developed EBV disease other than PTLD. Those with the latter had immunosuppression temporarily stopped and were started on ganciclovir. Viral loads developed and peaked in some patients while they were on intravenous ganciclovir. However, there were no cases of PTLD in the high risk group, while two cases occurred in the low risk group. These two patients were felt to be likely falsely labelled as low risk due to the presence of transplacental maternal antibody. While these results are promising, the study was limited by a small sample size. In addition, the study was not designed to evaluate the effects due to the reduction of immunosuppression versus those due to ganciclovir.

Based on the current evidence, there is the need for well-designed, multicentre trials to evaluate preventive strategies for EBV diseases after transplantation. In this regard, the role of ganciclovir alone or in combination with immunoglobulin needs to be defined. Among the approaches being considered are those employing prophylaxis regimens or pre-emptive treatment. Sample size requirements for such studies vary in relation to the desired outcome measured. However, as with HIV studies employing viral load as an outcome measure, the use of EBV viral load as an outcome variable may allow for smaller, more efficient and feasible studies.
Treatment of EBV-related PTLD: The treatment of PTLD is suboptimal for several reasons. Besides the inherent difficulties in the treatment of malignant disorders, a paucity of multicentre clinical trials of different treatment options makes it difficult for studies to have sufficiently large enough sample sizes to allow for clear conclusions to be drawn. In addition, there is the absence of a clear consensus definition of PTLD. This is related in part to a lack of a standardized approach to the pathology of PTLD.

It is generally accepted that the definitive diagnosis of EBV-induced PTLD can only be made by tissue diagnosis (needle biopsy, open surgical biopsy or cytology) demonstrating the 'appropriate' histopathological findings of PTLD accompanied by laboratory evidence of EBV infection. One approach to the classification of PTLD is the system proposed by Harris et al (52). Ideally, the classification of PTLD should take into account the cell type (B versus $T$ versus null), the histology, the number and phenotype of infiltrating cells, the clonality of B and T cells, and the EBV status of the tumour. With respect to the latter, there are different criteria for the evaluation of EBV within PTLD. In this situation, EBV may be detected by EBER2 or latent membrane protein 1 expression and may be expressed as E0 (EBV negative), E1 (EBV present, not further categorized), E2 (EBV present, no clonal component seen), E3 (EBV present, monoclonal component seen) and Ex (specimen inadequate or no procedures performed to determine presence or absence of EBV). A similar approach has been proposed for the evaluation of clonality: CO (no evidence of monoclonal component); C1 (monoclonal component less than $50 \%$ of cells); C2 (monoclonal component $50 \%$ or more of cells); C3 (multiclonal or oligoclonal pattern); C4 (clonal pattern other than those listed above); and $\mathrm{Cx}$ (specimen inadequate for clonal determination or clonal determination not performed).

Other considerations to be included in a standardized approach to defining the pathology of PTLD take into account whether the cells are of donor or recipient origin and the EBV viral load at the time of diagnosis. In addition, potential therapeutic markers may be documented, for example the presence of CD20 expression, as well as oncogene expression (cmyc, ras, p53, BCL-6). To date, information from clinical trials on the management of EBV is very limited. Available data are based on anecdotal experience and are often difficult to interpret due in part to the fact that specific attempts at therapy are often performed in conjunction with a reduction in immunosuppression, making it difficult to evaluate the true efficacy of the individual therapeutic approaches. Among the various approaches that have been or may be considered are the following (5363): reduced immunosuppression; surgical resection or local irradiation; adoptive immunotherapy; alpha-interferon therapy; passive antibody therapy; antiviral agent treatment (ganciclovir, acyclovir); monoclonal B cell antibody therapy (CD21, CD24, CD20); and cytotoxic chemotherapy, among other modalities. 
Summary of panel discussion and consensus statements Laboratory surveillance:

Is EBV viral load surveillance useful after transplantation? There is evidence to support the use of EBV viral load surveillance after transplantation (level BII evidence). The following observations were made by the group:

- The utility of EBV viral load surveillance is limited by the lack of data on the natural history of EBV viral load after transplantation.

- There is a need for studies on the natural progression of EBV viremia after transplantation.

- There is need for standardization of viral load testing and the method of reporting.

- Routine viral load testing without evaluation is less desirable than testing in the setting of an evaluative study.

The group noted that while the major transplant centres have access to viral load testing, on-site testing is limited to very few centres. In addition, there is no firm consensus on the timing and scheduling of testing after transplantation. Surveillance protocols have been established by a number of centres, including the Pittsburgh group in the United States. In Canada, protocols have been established at Hôpital Ste-Justine and The Hospital for Sick Children for their on-site testing programs.

Given that there is no gold standard, which PCR testing technique should be used for EBV viral load testing?

No consensus on the optimal technique could be reached. While the concept of a central laboratory was considered as one approach toward standardization, it was felt that it was too premature to agree on a single testing approach given the lack of comparative evaluation. The group acknowledged the existence of several goals to be achieved. These include interinstitutional studies to compare different tests, standardization of reporting methods in terms of the units, and documentation of the correlation between different units.

If viral load testing is used, when should it be done in clinical practice?

EBV viral load testing is expected to be most informative in the following situations:

- Follow-up of (D+R-) patients (primary infection) (level BII evidence).

- Follow-up of (D-R-) patients who acquire primary infection after transplantation (level BII evidence).

- Ruling out the presence of PTLD: In this situation, the test is considered to have a poor positive predictive value but a high negative predictive value (level BII evidence).
- An investigative protocol (level BII evidence): The optimal use of this test.

How frequently should EBV PCR surveillance be performed? It was acknowledged that there is no consensus on this issue. A description of how surveillance is carried out in various centres may provide guidance for physicians wishing to establish EBV PCR surveillance in their centres.

At the Children's Hospital of Pittsburgh, viral load testing is done every two weeks for three months, then every month for three months, then every three to six months for a duration of one to two years. Testing is started one to two weeks after transplantation.

The approach at The Hospital for Sick Children is similar to the Pittsburgh approach. However, it was emphasized that the frequency of testing is adjusted according to the clinical situation and the type of transplanted organ. The frequency of testing is adjusted in relation to rejection episodes or the occurrence of CMV disease in EBV D+Rpatients.

At Hôpital Ste-Justine, testing is performed every week for $\mathrm{D}+\mathrm{R}$ - recipients, starting four weeks after transplantation. This is done for a period of 100 days. Testing is not usually performed on EBV-seropositive recipients. The frequency of testing is adjusted according to the patient's clinical profile, the degree of immunosuppression and the presence or absence of rejection. A comparison of the outcomes of these protocols may allow for the development of a consensus on the use of this test.

What is the appropriate management of high viral load values?

It was agreed that there is no consensus on this issue. Thus, this is handled on a case-by-case scenario basis. However, it was felt that ganciclovir and immunoglobulin should be considered in the following settings when viral load is high: primary infections close to the time of transplantation (within the first three months); the manifestation of symptomatic EBV diseases, eg, enteritis and bone marrow suppression; and concurrent rejection and antirejection therapy, notably the use of anti-T cell preparations. In addition to antivirals and immunoglobulin, reduction in immunosuppression may be considered on a case-by-case basis in patients who do not exhibit rejection (level III evidence).

What is the role of EBV serology in transplant recipients? There was agreement on the following:

- EBV serology is important in the pretransplant identification of the risk factors for PTLD (ie, the identification of $\mathrm{D}+\mathrm{R}$ - subjects) (level AII evidence). In this regard, the risk of PTLD may be reduced if it were possible to give EBV-seronegative recipients EBV-seronegative organs. However, this form of donor-recipient matching is often not a practical preventive strategy because of the limited supply of donor organs. 
- Serology has limited or no value after transplantation unless it is part of an evaluative study (level DIII evidence).

In summary, the main component of laboratory surveillance for EBV-related diseases after transplantation revolves around the use of sequential PCR testing to document the presence of infection and the magnitude of EBV load. Serological tests are of limited value.

EBV prophylaxis following transplantation:

What are the EBV-related events for which prophylaxis is perceived to be beneficial?

In addressing this question, it is necessary to consider the prevention of infection versus the prevention of disease. In this regard, the group identified two basic approaches modified from the CMV paradigm. In the first approach, surveillance is conducted and pre-emptive therapy given when a particular test (such as viral load) reaches a specific threshold. In the second approach, prophylaxis is administered to prevent disease caused by primary infection. Although in the case of EBV, evidence is lacking on the role of prophylaxis or pre-emptive therapy in either situation, if these are to be considered, they should be used to achieve the following goals.

- Prevention of primary infection.

- Prevention of symptomatic diseases, such as PTLDs; febrile syndromes, eg, a mononucleosis-like illness; and end organ diseases, such as bone marrow suppression, enteritis, hepatitis and encephalitis.

If the above entities are not prevented, it may be desirable to avoid their occurrence during peak immunosuppression in the early months after transplantation.

\section{What is the evidence supporting EBV prophylaxis?}

It was noted that the SCID mouse model of EBV prophylaxis may not adequately reflect the human situation. However, as noted earlier, some data support the use of EBV prophylaxis after transplantation (level BII evidence). There was strong support for multicentre trials on EBV prophylaxis or pre-emptive treatment. Trials involving EBVseronegative recipients were felt to be of high priority.

Do transplant centres currently use prophylaxis for EBV infection after transplantation?

The approach at the University of Pittsburgh is structured around research studies in progress. At the University of Cincinnati, ganciclovir prophylaxis is used. Protocols are generally experimental. In Canada, the approach varies. Most of the major Canadian transplant centres employ prophylaxis for $\mathrm{D}+\mathrm{R}-$ patients. In this regard, ganciclovir with or without immunoglobulin is given for 12 to 14 weeks. In one major Canadian transplant centre (Hôpital Ste-Justine), no prophylaxis is given unless recipients are CMV D+R-. The regimens used in the Canadian centres are summarized in Table 3. The doses and routes of administration of ganci-
TABLE 3

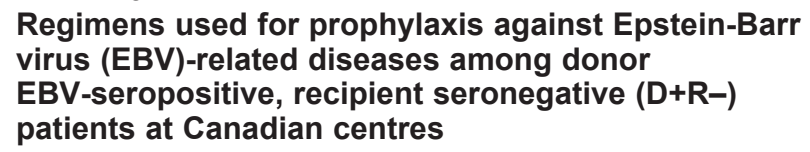

\begin{tabular}{|c|c|}
\hline Centres & Regimens (for EBV D+R-) \\
\hline Toronto Hospital (adults) & Ganciclovir $\times 12$ weeks \\
\hline $\begin{array}{l}\text { The Hospital for } \\
\text { Sick Children }\end{array}$ & $\begin{array}{l}\text { Ganciclovir + CytoGam* } \\
\quad \times 12 \text { weeks }\end{array}$ \\
\hline $\begin{array}{l}\text { University of Alberta Hospital } \\
\text { (adults and children) }\end{array}$ & Ganciclovir $\times 12$ weeks \\
\hline $\begin{array}{l}\text { Hôpital Ste-Justine } \\
\text { (children) }\end{array}$ & $\begin{array}{l}\text { No prophylaxis unless } \\
\text { CMV D+R- }\end{array}$ \\
\hline Montreal Children's Hospital & $\begin{array}{l}\text { Ganciclovir + CytoGam* } \\
\times 12 \text { weeks }\end{array}$ \\
\hline Winnipeg Children's Hospital & Ganciclovir $\times 12$ weeks \\
\hline $\begin{array}{l}\text { Royal University Hospital } \\
\text { (Saskatchewan) }\end{array}$ & $\begin{array}{l}\text { Guided by CMV prophylaxis; } \\
\text { all transplant recipients receive } \\
\text { CMV prophylaxis including } \\
\text { (CMV D-R-) }\end{array}$ \\
\hline $\begin{array}{l}\text { London Health Sciences } \\
\text { Centre (children) }\end{array}$ & $\begin{array}{l}\text { Guided by CMV prophylaxis; all } \\
\text { children get immunoglobulin } \\
\text { plus acyclovir } \times 3 \text { months }\end{array}$ \\
\hline
\end{tabular}

*Massachusetts Public Health Biologic Laboratories, USA. CMV Cytomegalovirus; $D-R-D o n o r$ EBV-seronegative, recipient seronegative

clovir in these locations are variable. The adult centres generally use oral ganciclovir on discharge from hospital after an initial period of intravenous ganciclovir. Oral ganciclovir is used in some older children. The dose of ganciclovir was $5 \mathrm{mg} / \mathrm{kg} / \mathrm{day}$ or $10 \mathrm{mg} / \mathrm{kg} /$ day initially (first two weeks) followed by $5 \mathrm{mg} / \mathrm{kg} /$ day.

Summary of panel discussion on treatment:

What is meant by reduced immunosuppression or withdrawal of immunosuppression in the treatment of PTLD? The panel discussed different approaches to the way reduction of immunosuppression and withdrawals are performed. Practices vary widely in Canada and the United States. Approaches include complete cessation and reduction in immunosuppression. It was clear that there is no consensus on the best approach, except for the fact that this modality of therapy is regarded as an essential component of the treatment of PTLD. There was general agreement that when reduction of specific agents was considered by panel members, the level of reduction was generally in the region of $50 \%$ (level III evidence).

If immunosuppression is modified, what is the duration of this reduction or withdrawal before alternative therapy is considered?

Approaches vary widely according to organ transplant types and individual patient differences. Participants indicated that in some situations, patients with PTLD who had withdrawal of immunosuppression showed evidence of rejection after about two to three weeks. It was pointed out that 
the onset of rejection might herald the return of functional cytotoxic T lymphocyte activity, which is essential in the control of EBV-related lymphoproliferation. Duration was generally felt to be two to three weeks (level III evidence).

One issue is whether EBV viral load could be used as a surrogate marker of response or a predictor of response. Evidence is lacking, but it was felt that, wherever possible, the monitoring of viral load following treatment might provide a basis for when to reintroduce immunosuppression in patients who are showing no evidence of rejection.

\section{What is the role of antivirals and immunoglobulin in the treatment of PTLD?}

The majority of panel members recommended the use of ganciclovir and immunoglobulin in the initial management of PTLD (level BIII evidence). In this regard, ganciclovir is preferred over acyclovir because of its greater in vitro activity against the EBV.

After modification of immunosuppression, tumour resection (where possible) and the use of ganciclovir and immunoglobulin, what other modalities should be tried?

Data available on the different treatment modalities were generally anecdotal experiences. The use of anti-CD20 monoclonal antibody may be considered. However, it is important to determine the presence of CD20 markers. This treatment modality was favoured over interferon as the next step in the treatment after modification of immunosuppression, surgical debulking, ganciclovir and immunoglobulin. However, it was noted that the oncologists present would consider reduction of tumour burden with chemotherapy at this stage. Concern was expressed about the potential for a cytokine storm with monoclonal antibody. However, it was noted that there is the potential for cytokine storm following chemotherapy and tumour lysis even in patients receiving corticosteroids. The use of monoclonal antibody is favoured before the use of chemotherapy except in the case of central nervous system (CNS) disease (level III evidence).

\section{When should chemotherapy be considered as first-line treatment?}

For patients with PTLD involving the CNS, early use of traditional cancer chemotherapy should be considered (level III evidence). Patients with late localized disease may be less likely to respond to reduction in immunosuppression. In this situation, chemotherapy should be considered with or without surgical resection because these lesions may include $\mathrm{T}$ cell and other tumours (eg, plasmacytic lymphomas) (level III evidence). Local radiotherapy may also be indicated in PTLD involving the CNS.

\section{CONCLUSIONS}

EBV-related PTLDs represent a significant challenge for transplant recipients. In such patients, strategies need to be employed to reduce the risk of primary infection in EBVseronegative patients and to prevent symptomatic diseases in those who are EBV-seropositive. Early diagnosis of PTLD is essential. In this regard, EBV quantitative or semiquantitative PCR testing may aid in surveillance; however, additional research needs to be directed at improving the sensitivity, specificity and predictive values of this and other testing modalities. Multicentre trials are needed to evaluate the role of various regimens in the prevention of PTLD in high risk patients. Until such data are available, it seems appropriate to consider a prophylaxis strategy patterned after CMV prophylaxis for high risk transplant recipients (donor seropositive, recipient seronegative). While reduction of immunosuppression is the mainstay of the treatment of PTLD, there is a need for multicentre trials of different treatment modalities. Depending on the outcome parameters, the sample sizes for these studies need not be prohibitive. Such trials would be facilitated by agreement across centres on a uniform approach to the pathological classification of PTLD.

\section{APPENDIX I}

The laboratory determination of viral load in the peripheral blood

Viral load testing at Hôpital Ste-Justine, Montreal: DNA preparation from PBMCs: The technique uses known concentrations of boiled cell suspensions. Briefly, blood is collected in heparinized Vacutainer tubes (Becton Dickinson, USA) and PBMCs are separated by FicollHypaque density centrifugation, washed in PBS, counted, resuspended in deionized water to an initial concentration of 50,000 cells $/ 20 \mu \mathrm{L}$, and boiled. This cell suspension is diluted further to yield 10,000 and 1000 cells/20 $\mu \mathrm{L}$.

Amplification of EBV DNA: Boiled suspensions containing $50,000,10,000$ and $1000 \mathrm{PBMCs} / 20 \mu \mathrm{L}$ volume are amplified in duplicate, thus giving rise to a semiquantitative viral load determination. New transplant recipients, however, are initially screened at the initial concentration of 50,000 cells $/ 20 \mu \mathrm{L}$ and amplified in triplicate. Primers selected are from a conserved region within the BMLF I fragment of the EBV genome:

\section{PI (1182): 5'-CACCACCTTGTTTTGACGGG-3' \\ P2 (1181):5'-GTCAACCAACAAGGACACAT-3'}

The amplified fragment is 304 base pairs (bp) in length. The PCR reaction is performed in duplex with a set of primers, G26 and G27, amplifying a DNA fragment within the HLADQ alpha gene yielding a $242 \mathrm{bp}$ band to indicate the presence of cellular DNA. G26 and G27 primers have the following sequence:

\section{G26:5'-GTGCTGCAGGTGTAAACTTGTACCAG-3' G27:5'-CACGGATCCGGTAGCAGCGGTAGAGTTG-3'}

A final reaction volume of $100 \mu \mathrm{L}$ is used. Reaction mixtures contain: $50 \mathrm{mM}$ potassium chloride, $20 \mathrm{mM}$ Trishydrogen chloride ( $\mathrm{pH}$ 8.4), $1.5 \mathrm{mM}$ magnesium dichloride, $200 \mu \mathrm{M}$ each of deoxynucleotide triphosphate (dATP, dCTP, dGTP, dUTP) and $100 \mathrm{pM}$ each of the four 
oligonucleotide primers. The mixture is overlaid with $75 \mu \mathrm{L}$ of mineral oil, and $20 \mu \mathrm{L}$ of template DNA (cell suspension) is added through the oil along with $1 \mathrm{U}$ uracyl $\mathrm{N}$-glycosylase (UNG, GIBCO-BRL, USA) enzyme to prevent PCR carry-over. The reaction mixture is then incubated at $37^{\circ} \mathrm{C}$ for $10 \mathrm{~min}$ and thereafter heated at $94^{\circ} \mathrm{C}$ for another $10 \mathrm{~min}$ ('hot start', which also serves to inactivate the $\mathrm{UNG}$ ). Lastly, Taq polymerase is added (2.5 U) to each tube followed by a 35-cycle amplification run in a PerkinElmer 480 thermal cycler (Canada) using the following parameters: $1 \mathrm{~min}$ denaturation at $94^{\circ} \mathrm{C} ; 1.5 \mathrm{~min}$ annealing at $55^{\circ} \mathrm{C}, 1.5 \mathrm{~min}$ elongation at $74^{\circ} \mathrm{C}$; and a 10 -min extension at $74^{\circ} \mathrm{C}$ at the end of the last cycle.

Detection of EBV PCR products: A volume consisting of $10 \mu \mathrm{L}$ of each amplified product is loaded onto a $1.8 \%$ agarose gel containing ethidium bromide. After alkali treatment, Southern transfer onto a nylon membrane is performed overnight in a 10x solution of SSC. The blot is then hybridized for $2 \mathrm{~h}$ to $16 \mathrm{~h}$ with a digoxigenin-labelled oligonucleotide probe (using DIG Oligonucleotide 3'-EndLabeling Kit [Boehringer Mannheim, Germany]) specific for an internal region of the amplified EBV fragment. The following probe sequence was used:

\section{5'-CCGCGGGAGCTAGGGGCAGG-3'}

The blot is washed and then incubated using a purified anti-DIG Fab antibody preparation conjugated with alkaline phosphatase followed by addition of a chemiluminescent substrate (CSPD) (DIG Luminescent Detection Kit [Boehringer Mannheim, Germany]). The bands are visualized following a $2 \mathrm{~h}$ exposure to Kodak XAR film (USA) at room temperature.

Method of quantifying EBV load at The Hospital for Sick Children, Toronto: PBMCs are separated by centrifugation on a Ficoll-Hypaque cushion (Pharmacia, USA). PBMCs are resuspended in PBS and counted on an automated cell counter (Coulter HmX, USA). Cells are then serially diluted to obtain four aliquots of $10^{6}, 10^{5}, 10^{4}, 10^{3}$ cells, respectively. Total DNA is extracted from each aliquot using the QIAamp blood kit (Qiagen, Germany) and the DNA is resuspended in $200 \mu \mathrm{L}$ of double distilled molecular grade water. For the PCR analysis, $10 \mu \mathrm{L}$ of the DNA solution is used.

PCR: The PCR is performed using the EBV-specific primers 5' TTTGCCAGCCTCTACCCG $3^{\prime}$ and 5' GCCAGCAGCTTCTTGATGG 3'. The primers bracket a $234 \mathrm{bp}$ fragment of the EBV DNA polymerase gene. Reactions are performed in a total volume of $50 \mu \mathrm{L}$. The master mix contained in each tube, $5 \mu \mathrm{L}$ of $10 \times$ Cetus buffer II (Perkin-Elmer, Canada), $5 \mu \mathrm{L}$ of $25 \mathrm{mM}$ magnesium dichloride, $5 \mu \mathrm{L}$ of dNTPs mix (each dNTP $2 \mathrm{mM}$ ), $5 \mu \mathrm{L}$ of each primer stock solution ( $10 \mathrm{pmols} / \mu \mathrm{L})$, $14.5 \mu \mathrm{L}$ molecular grade water and $0.5 \mu \mathrm{L}$ AmpliTaq Gold (Perkin-Elmer, Canada) for a volume of $40 \mu \mathrm{L}$. To each $40 \mu \mathrm{L}$ aliquot of master mix is added $10 \mu \mathrm{L}$ of template
DNA solution. The PCR is performed in a Robocycler 40 (Stratagene, USA) using the following cycling parameters: $10 \mathrm{~min}$ at $95^{\circ} \mathrm{C}$, then 40 cycles consisting of $1 \mathrm{~min}$ at $95^{\circ} \mathrm{C}, 1 \mathrm{~min}$ at $64^{\circ} \mathrm{C}$, and $1 \mathrm{~min}$ at $72^{\circ} \mathrm{C}$; after completion of the last cycle a final incubation at $72^{\circ} \mathrm{C}$ for $3 \mathrm{~min}$ is performed. Amplicons are detected by agarose gel electrophoresis and ethidium bromide staining. The sensitivity of the PCR is established with DNA extracted from serial dilutions of Namalwa cell line (which contained 2 EBV genome copies/cell). EBV can be reproducibly detected from the equivalent of one cell, and it is conservatively estimated that the PCR sensitivity is between one and 10 genome copies. Using this assay, no amplicons are obtained from DNA of EBV-negative cells or from herpes simplex virus type 1 DNA and CMV DNA templates.

The semiquantitative estimate of EBV-infected cell load is defined as the smallest aliquot of the cells positive by PCR (eg, $10^{5}$ ), which is then converted as a proportion of the positive cells in $10^{6}$ cells; this is expressed as a range to account for the fact that only a fraction of the extracted DNA was used in the PCR (eg, 10 to 100 cells $/ 10^{6}$ cells). The ranges that can be reported are, therefore: no EBV detected in $10^{6}$ PBMCs; 1 to $10 ; 10$ to $100 ; 100$ to 1000 ; and greater than 1000 cells/106 $\mathrm{PBMCs}$, respectively.

\section{APPENDIX 2 \\ Canadian PTLD Workshop participants - 1999}

Philip Acott, IWK Grace Health Centre, Halifax, Nova Scotia; Caroline Alfieri, Centre de Recherche de L'Hôpital Ste-Justine, Montreal, Quebec; Upton Allen, The Hospital for Sick Children, Toronto, Ontario; Gerald Arbus, The Hospital for Sick Children, Toronto, Ontario; Sandra Arnold, The Hospital for Sick Children, Toronto, Ontario; Paul Atkison, London HSC-Victoria Campus, London, Ontario; Lorraine Bell, The Montreal Children's Hospital, Montreal, Quebec; Patricia Birke, Health Science Centre, Winnipeg, Manitoba; Rose Cheung, The Hospital for Sick Children, Toronto, Ontario; Sandra Cockfield, University of Alberta, Edmonton, Alberta; Dele Davies, Alberta Children's Hospital, Calgary, Alberta; Louise Deschenes, CHUM, Pav Hotel-Dieu, Montreal, Quebec; Simon Dobson, British Columbia's Children's and Women's Hospital, Vancouver, British Columbia; Carol Durno, The Hospital for Sick Children, Toronto, Ontario; Annie Fecteau, The Hospital for Sick Children, Toronto, Ontario; Dennis Geary, The Hospital for Sick Children, Toronto, Ontario; Tom Gross, University of Cincinnati, Cincinnati, Ohio; Bo-Yee Ngan, The Hospital for Sick Children, Toronto, Ontario; Anne Opavsky, The Hospital for Sick Children, Toronto, Ontario; Jutta Preiksaitis, University of Alberta, Edmonton, Alberta; Ahmed Shoker, Royal University Hospital, Saskatoon, Saskatchewan; Lise StJean, CHUM, Pav Hotel-Dieu, Montreal, Quebec; Dorothy Moore, The Montreal Children's Hospital, Montreal, Quebec; Bernadette O'Hare, The Hospital for Sick Children, Toronto, Ontario; Martin Petric, The Hospital for Sick Children, Toronto, Ontario; Stanley Read, The 
Hospital for Sick Children, Toronto, Ontario; David Snydman, Tufts University School of Medicine, Boston, Massachusetts; Bruce Tapiero, Hôpital Ste-Justine, Montreal, Quebec; Kevin Fonseco, Public Health Laboratory, Calgary, Alberta; Sumita Fleming, The Hospital for Sick Children, Toronto, Ontario; Sarah Forgie, Children's Hospital, Winnipeg, Manitoba; Michael Green, Children's Hospital of Pittsburgh, Pittsburgh, Pennsylvania; Diane Hébert, The Hospital for Sick Children, Toronto, Ontario; Helen Heurter, The Hospital for Sick Children, Toronto, Ontario; Atul Humar, The Toronto Hospital, Toronto, Ontario; Kevan Jacobson, British Columbia's Children's and Women's Health Centre, Vancouver, British Columbia; Nicola Jones, The Hospital for Sick Children, Toronto, Ontario; Susan

\section{REFERENCES}

1. Pope JH, Horne MK, Scott W. Transformation of foetal human leukocytes in vitro by filtrates of a human leukemic cell line containing herpes-like virus. Int J Cancer 1968;3:857-66.

2. Hanto DW, Frizzera G, Gajl-Peczalska KJ, et al. Epstein-Barr virus (EBV) induced B-cell lymphoma after renal transplantation. N Engl J Med 1982;306:913-8.

3. Starzl TE, Nalesnik MA, Porter KA, et al. Reversibility of lymphomas and lymphoproliferative lesions developing under cyclosporin-steroid therapy. Lancet 1984;i:583-7.

4. Shapiro RS, McClain K, Frizzera G, et al. Epstein-Barr virusassociated B cell lymphoproliferative disorders following bone marrow transplantation. Blood 1988;71:1234-43.

5. Nalesnik MA, Jaffe R, Starzl TE, et al. The pathology of posttransplant lymphoproliferative disorders occurring in the setting of cyclosporin A-prednisone immunosuppression. Am J Pathol 1988;133:173-92.

6. Young L, Alfieri C, Hennessy K, et al. Expression of Epstein-Barr virus transformation-associated genes in tissues of patients with EBV lymphoproliferative disease. N EngI J Med 1989;321:1080-5.

7. Hanto DW, Gajl-Peczalska KJ, Frizzera G, et al. Epstein-Barr virus (EBV) induced polyclonal and monoclonal B-cell lymphoproliferative diseases occurring after renal transplantation: Clinical, pathologic, and virologic findings and implications for therapy. Ann Surg 1983;198:356-69.

8. Ho M, Miller G, Atchison RW, et al. Epstein-Barr virus infections and DNA hybridization studies in posttransplantation lymphoma and lymphoproliferative lesions: The role of primary infection. J Infect Dis 1985;152:876-8.

9. Savoie A, Perpête C, Carpentier L, Joncas J, Alfieri C. Direct correlation between the load of Epstein-Barr virus-infected lymphocytes in the peripheral blood of pediatric transplant patients and risk of lymphoproliferative disease. Blood 1994;83:2715-22.

10. Ho M, Jaffe R, Miller G, et al. The frequency of Epstein-Barr virus infection and associated lymphoproliferative syndrome after transplantation and its manifestations in children. Transplantation 1988;45:719-27.

11. Cox KL, Lawrence-Miyasaki LS, Garcia-Kennedy R, et al. An increased incidence of Epstein-Barr virus infection and lymphoproliferative disorder in young children on FK506 after liver transplantation. Transplantation 1995;59:524-9.

12. Newell KA, Alonso EM, Whitingham PF, et al. Posttransplant lymphoproliferative disease in pediatric liver transplantation. Transplantation 1996;62:370-5.

13. Cen H, Breinig MC, Atchison RW, Ho M, McKnight JLC. Epstein-Barr virus transmission via the donor organs in solid organ transplantation: polymerase chain reaction and restriction fragment length polymorphism analysis of IR2, IR3, and IR4. J Virol 1991;65:976-80.

14. Alfieri C, Tanner J, Carpentier L. Epstein-Barr virus transmission from a blood donor to an organ transplant recipient with recovery of the same virus strain from the recipient's blood and oropharynx. Blood 1996;87:812-7.
King, The Hospital for Sick Children, Toronto, Ontario; Raymond Tellier, The Hospital for Sick Children, Toronto, Ontario; Jean Tchervenkov, Royal Victoria Hospital, Montreal, Quebec; Lee Anne Tibbles, University of Calgary, Calgary, Alberta; Dat Tran, The Hospital for Sick Children, Toronto, Ontario; Samia Wasfy, The Hospital for Sick Children, Toronto, Ontario; Sheila Weitzman, The Hospital for Sick Children, Toronto, Ontario; Jean Luc Wolff, Université de Sherbrooke, Quebec, Quebec

ACKNOWLEDGEMENTS: The workshop was supported by an unrestricted educational grant from Genesis Bio-Pharmaceuticals Inc and MedImmune, Inc.
15. Henle G, Henle W, Clifford P, et al. Antibodies to EB virus in Burkitt's lymphoma and control groups. J Natl Cancer Inst 1969;43:1147-57.

16. Henle G, Henle W. Observations on childhood infections with the Epstein-Barr virus. J Infect Dis 1970;121:303-10.

17. Breinig MK, Zitelli B, Starzl TE, Ho M. Epstein-Barr virus, cytomegalovirus and other viral infections in children after liver transplantation. J Infect Dis 1987;156:273-9.

18. Green M, Michaels MG, Webber SA, Rowe D, Reyes J. The management of Epstein-Barr virus associated post-transplant lymphoproliferative disorders in pediatric solid-organ transplant recipients. Pediatr Transplant 1999;3:271-81.

19. Howard TK, Klintmalm GB, Stone MJ. Lymphoproliferative disorder masquerading as rejection in liver transplant recipients - an early aggressive tumor with atypical presentation. Transplantation 1992;53:1145-7.

20. Preiksaitis JK, Diaz-Mitoma F, Mirzayans F, Roberts S, Tyrrell DLJ. Quantitative oropharyngeal Epstein-Barr virus shedding in renal and cardiac transplant recipients: relationship to immunosuppressive therapy, serologic responses, and the risk of posttransplant lymphoproliferative disorder. J Infect Dis 1992;166:986-94.

21. Reedman BM, Klein G. Cellular localization of an Epstein-Barr virus (EBV)-associated complement-fixing antigen in producer and nonproducer lymphoblastoid cell lines. Int J Cancer 1973;11:499-520.

22. Pedneault L, Lapointe N, Alfieri C, et al. Antibody responses to two Epstein-Barr virus (EBV) nuclear antigens (EBNA-I and EBNA-2) during EBV primary infection in children born to mothers infected with human immunodeficiency virus. Clin Infect Dis 1996;23:806-9.

23. Henle G, Henle W. Immunofluorescence in cells derived from Burkitt's lymphoma. J Bacteriol 1966;91:1248-56.

24. Henle W, Henle G, Niederman JC, Klemola E, Haltia K. Antibodies to early antigens induced by Epstein-Barr virus in infectious mononucleosis. J Infect Dis 1971;124:58-67.

25. Randhawa PS, Jaffe R, Demetris AJ, et al. Expression of Epstein-Barr virus-encoded small RNA (by the EBER-I gene) in liver specimens from transplant recipients with post-transplantation lymphoproliferative disease. N Engl J Med 1992;327:1710-4.

26. Rocchi G, de Felici A, Ragona G, Heinz A. Quantitative evaluation of Epstein-Barr virus-infected mononuclear peripheral blood leukocytes in infectious mononucleosis. N Engl J Med 1977;296:132-4.

27. Riddler SA, Breinig MC, McKnight JLC. Increased levels of circulating Epstein-Barr virus (EBV)-infected lymphocytes and decreased EBV nuclear antigen antibody responses are associated with the development of posttransplant lymphoproliferative disease in solid-organ transplant recipients. Blood 1994;84:972-84.

28. Kenagy DN, Schlesinger Y, Wesk K, Ritter JH. Epstein-Barr virus DNA in peripheral blood leukocytes of patients with posttransplant lymphoproliferative disease. Transplantation 1995;60:547-54.

29. Lucas KG, Burton RL, Zimmerman SE, et al. Semiquantitative, Epstein-Barr virus (EBV) polymerase chain reaction for the 
determination of patients at risk for EBV-induced lymphoproliferative disease after stem cell transplantation. Blood 1998;91:3654-61.

30. Bai X, Hosler G, Rogers BB, Dawson DB, Scheuermann RH. Quantitative polymerase chain reaction for human herpesvirus diagnosis and measurement of Epstein-Barr virus burden in posttransplant lymphoproliferative disorder. Clin Chem $1997 ; 43: 1843-9$

31. Nakazawa Y, Chisuwa H, Ikegami T, et al. Efficacy of quantitative analysis of Epstein-Barr virus-infected peripheral blood lymphocytes by in situ hybridization of EBER-1 after living-related liver transplantation: a case report. Transplantation 1997;63:1363-6.

32. Rowe DT, Qu L, Reyes J. Use of quantitative competitive PCR to measure Epstein-Barr virus genome load in the peripheral blood of pediatric transplant patients with lymphoproliferative disorders. J Clin Microbiol 1997;35:1612-5.

33. Kimura H, Morita M, Yabuta Y. Quantitative analysis of Epstein-Barr virus load by using a real-time PCR assay. J Clin Microbiol 1999;37:132-6.

34. Alfieri C. EBV infections in transplant recipients: Current challenges. Canadian Workshop. Toronto, December 3, 1999.

35. Allen UD, Hebert D, Tran D, et al. Utility of semiquantitative polymerase chain reaction for Epstein-Barr virus among pediatric solid organ transplant recipients with and without post-transplant lymphoproliferative disease. Clin Infect Dis 2001;33:145-50.

36. Zaia JA. Prevention and treatment of cytomegalovirus pneumonia in transplant recipients. Clin Infect Dis 1993;17(Suppl 2):S392-9.

37. Craig FE, Gulley ML, Banks PM. Posttransplantation lymphoproliferative disorders. Am J Clin Pathol 1993;99:265-76.

38. Penn I. Tumour incidence in human allograft recipients. Transplant Proc 1979;11:1047-51.

39. Walker RC, Marshall WF, Strickler JG, et al. Pretransplant assessment of the risk of lymphoproliferative disorder. Clin Infect Dis 1995;20:1346-53

40. Boyle TJ, Tamburini M, Berend KR, Kizilbash AM, Borowitz MJ, Lyerly HK. Human B-cell lymphoma in severe combined immunodeficient mice after active infection with Epstein-Barr virus. Surgery 1992;112:378-86.

41. Abedi MR, Linde A, Christensson B, et al. Preventive effect of IgG from EBV-seropositive donors on the development of human lymphoproliferative disease in SCID mice. Int J Cancer 1997;71:624-9.

42. Kuo PC, Dafoe DC, Alfrey EJ, Sibley RK, Scandling JD. Posttransplant lymphoproliferative disorders and Epstein-Barr virus prophylaxis. Transplantation 1995;59:135-8.

43. Trigg ME, Finlay JL, Sondel PM. Prophylaxis acyclovir in patients receiving bone marrow transplants. N Engl J Med 1985;312:1708-9.

44. Zutter MM, Martin PJ, Sale GE, et al. Epstein-Barr virus lymphoproliferation after bone marrow transplantation. Blood 1988;72:520-9.

45. Renard TH, Andrews WS, Foster ME. Relationship between OKT3 administration, EBV seroconversion and the lymphoproliferative syndrome in pediatric liver transplant recipients. Transplant Proc 1991;23:1473-6.

46. Shapiro RS, McClain K, Frizzera G, et al. Epstein-Barr virus associated B cell lymphoproliferation disorders following bone marrow transplantation. Blood 1988;71:1234-43.

47. Green M, Kaufman M, Wilson J, Reyes J. Comparison of intravenous ganciclovir followed by oral acyclovir with intravenous ganciclovir alone for prevention of cytomegalovirus and Epstein-Barr virus disease after liver transplantation in children. Clin Infect Dis 1997;25:1344-9.

48. McDiarmid SV, Jordan S, Lee GS, et al. Prevention and preemptive therapy of posttransplant lymphoproliferative disease in pediatric liver recipients. Transplantation 1998;66:1604-11.

49. Keay S, Oldbach D, Wiland A, et al. Posttransplantation lymphoproliferative disorder associated with OKT3 and decreased antiviral prophylaxis in pancreas transplant recipients. Clin Infect Dis 1998;26:596-600.

50. Davis CL, Harrison KL, McVicar JP, Forg P, Bronner M, Marsh CL. Antiviral prophylaxis and the Epstein-Barr virus-related posttransplant lymphoproliferative disorder. Clin Transpl 1995;9:53-9.

51. Darenkov IA, Marcarelli MA, Basadonna GP, et al. Reduced incidence of Epstein-Barr virus-associated posttransplant lymphoproliferative disorder using preemptive antiviral therapy. Transplantation 1997;64:848-52.

52. Harris NL, Ferry JA, Swerdlow SH. Posttransplant lymphoproliferative disorders: summary of Society for Hematopathology Workshop. Semin Diagn Pathol 1997;14:8-14.

53. Hanto DW, Gajl-Peczalska KJ, Balfour HH, Simmons RL, Najarian JS. Acyclovir therapy of Epstein-Barr virus-induced posttransplant lymphoproliferative diseases. Transplant Proc 1985;27:89-92

54. Hanto DW, Frizzera G, Gajl-Peczalska KJ, et al. Epstein-Barr virusinduced B-cell lymphoma after renal transplantation: acyclovir therapy and transition from polyclonal to monoclonal B-cell proliferation. N Engl J Med 1982;306:913-8.

55. Shapiro RS, Chauvenet A, McGuire W, Pearson A, Craft AW, McGlave P. Treatment of B-cell lymphoproliferative disorders with interferon alfa and intravenous gamma globulin. N Engl J Med 1988;318:1334.

56. Benkerrou M, Durandy AA, Fischer A. Therapy for transplant related lymphoproliferative diseases. Hematol Oncol Clin North Am 1993;7:467-75.

57. Papadopoulos EB, Ladanyi M, Emanuel D, et al. Infusions of donor leukocytes to treat Epstein-Barr virus-associated lymphoproliferative disorders after allogeneic bone marrow transplantation. N Engl J Med 1994;330:1185-91.

58. Stephan JL, Le Deist F, Blanche S. Treatment of central nervous system B lymphoproliferative syndrome by local infusion of B cellspecific monoclonal antibody. Transplantation 1992;54:246-9.

59. Delone P, Corkill J, Jordan M, et al. Successful treatment of EpsteinBarr infection with ganciclovir and cytomegalovirus hyperimmune globulin following kidney transplantation. Transplant Proc 1995;27:58-9.

60. Swinnen LJ, Martin M, Carr TJ, Costanzo MR, Fisher RI. Aggressive treatment for postcardiac transplant lymphoproliferation. Blood 1995;86:3333-40.

61. Faro A. Interferon-alpha and its effects on post-transplant lymphoproliferative disorders. Springer Semin Immunopathol 1998;20:425-6.

62. Davis CL, Wood BL, Sabath DE, Joseph JS, Stehman-Breen C, Broudy VC. Interferon-alpha treatment of posttransplant lymphoproliferative disorder in recipients of solid organ transplants. Transplantation 1998;66:1770-9.

63. Benkerrou M, Jais JP, Leblond V, et al. Anti-B-cell monoclonal antibody treatment of severe posttransplant B-lymphoproliferative disorder: prognostic factors and long-term outcome. Blood 1998;92:3137-47. 


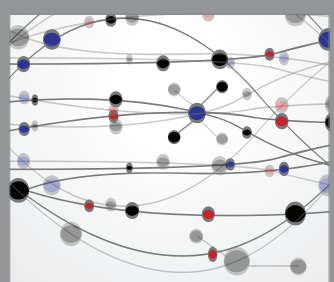

The Scientific World Journal
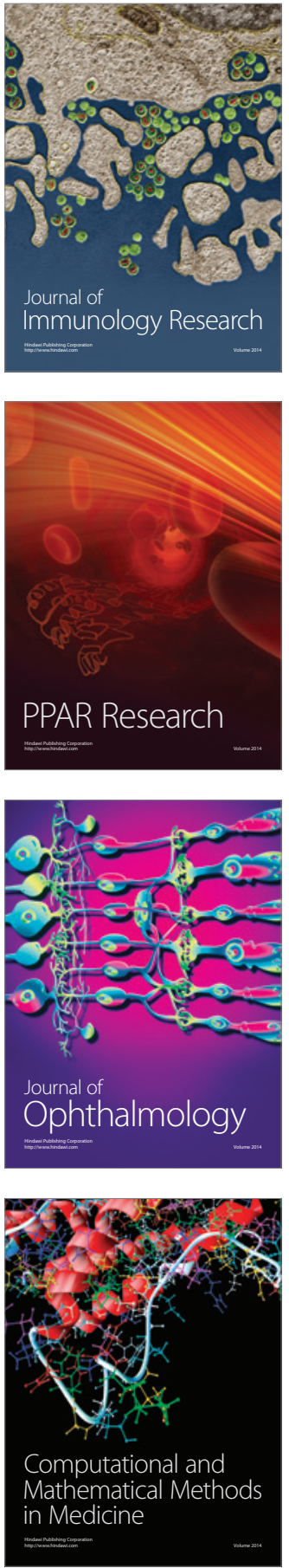

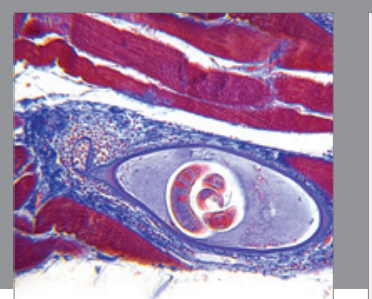

Gastroenterology Research and Practice

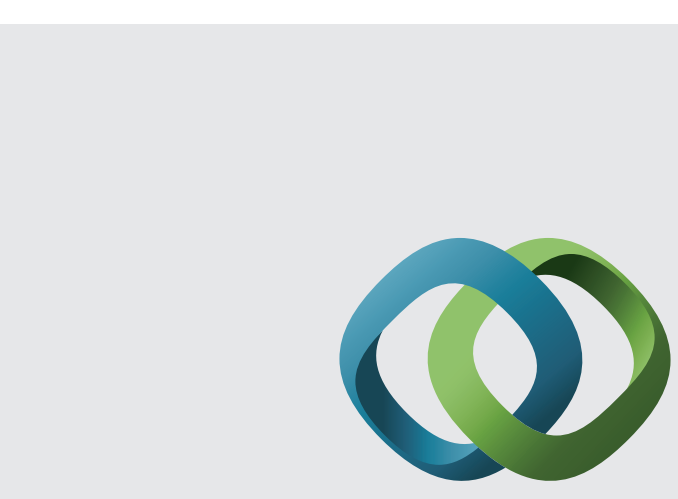

\section{Hindawi}

Submit your manuscripts at

http://www.hindawi.com
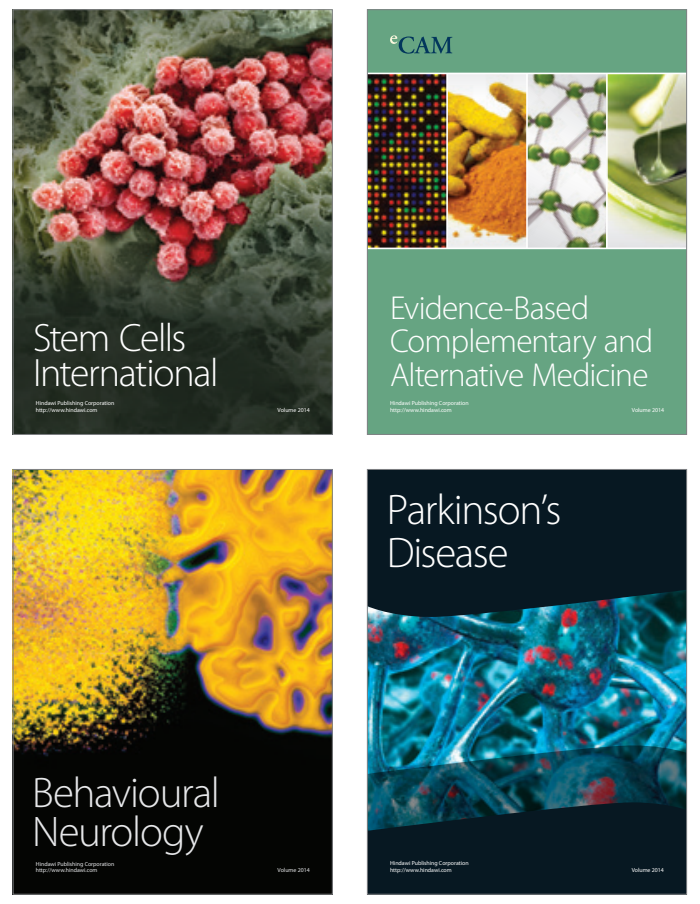
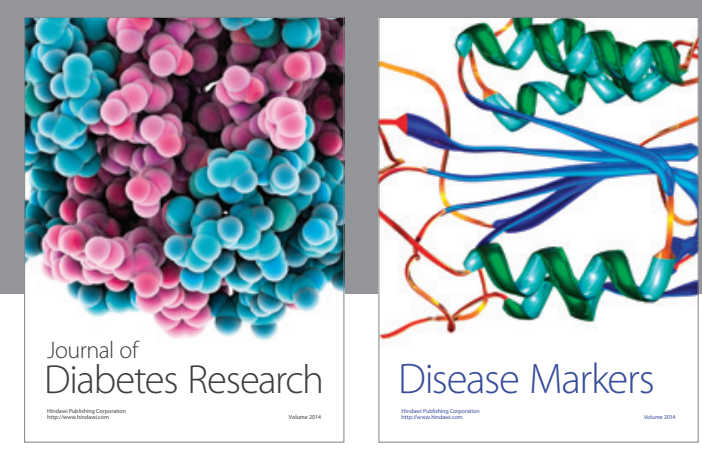

Disease Markers
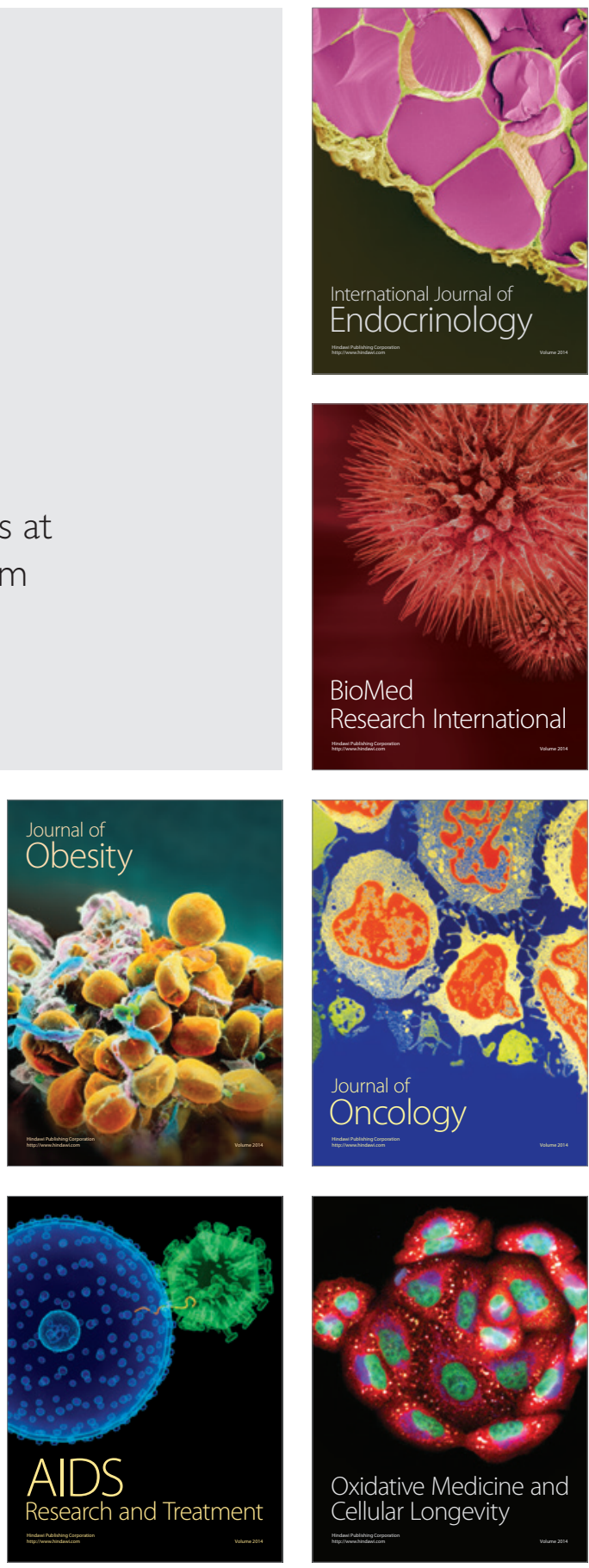